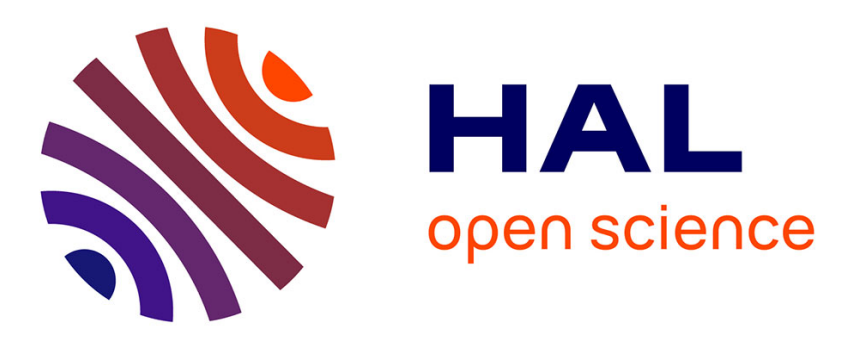

\title{
Long-term functional outcomes after artificial urinary sphincter implantation in men with stress urinary incontinence
}

Priscilla Léon, Emmanuel Chartier-Kastler, Morgan Rouprêt, Vanina Ambrogi, Pierre Mozer, Véronique Phé

\section{To cite this version:}

Priscilla Léon, Emmanuel Chartier-Kastler, Morgan Rouprêt, Vanina Ambrogi, Pierre Mozer, et al.. Long-term functional outcomes after artificial urinary sphincter implantation in men with stress urinary incontinence. BJU International, 2014, 115 (6), pp.951-957 10.1111/bju.12848 . hal-01103276

\section{HAL Id: hal-01103276 \\ https: / hal.sorbonne-universite.fr/hal-01103276}

Submitted on 14 Jan 2015

HAL is a multi-disciplinary open access archive for the deposit and dissemination of scientific research documents, whether they are published or not. The documents may come from teaching and research institutions in France or abroad, or from public or private research centers.
L'archive ouverte pluridisciplinaire HAL, est destinée au dépôt et à la diffusion de documents scientifiques de niveau recherche, publiés ou non, émanant des établissements d'enseignement et de recherche français ou étrangers, des laboratoires publics ou privés. 
Long-term functional outcomes after artificial urinary sphincter (AMS 800®) implantation in men with stress urinary incontinence

Priscilla Léon ${ }^{1}$ M.D, Emmanuel Chartier-Kastler ${ }^{1}$ M.D, Ph.D, Morgan Rouprêt ${ }^{1}$ M.D, Ph.D, Vanina Ambrogi ${ }^{2}$ M.D, Pierre Mozer ${ }^{1}$ M.D, Ph.D, Véronique Phé ${ }^{1 *}$ M.D.

${ }^{1}$ Pitié-Salpétrière Academic Hospital, Department of Urology, Assistance Publique-Hôpitaux de Paris, Pierre and Marie Curie Medical School, Paris 6 University, Paris, France

${ }^{2}$ Pitié-Salpêtrière Academic Hospital, Department of Statistics, Assistance Publique-Hôpitaux de Paris, Pierre and Marie Curie Medical School, Paris 6 University, Paris, France

Running title: Artificial urinary sphincter in men

$\underline{\text { Keywords (MeSH) }}$ : Urinary incontinence; urinary sphincter; survival; outcomes

Word count: abstract (296); manuscript (2345)

*Corresponding author:

Véronique Phé, MD

Hôpital Pitié-Salpêtrière, Service d'urologie, 47-83 boulevard de l'hôpital, 75651 Paris Cedex 13, France

Phone: +33663231534; Email: veronique.phe@gmail.com 


\begin{abstract}
Background. Artificial urinary sphincter (AUS) is the gold standard surgical treatment of male stress urinary incontinence (SUI) with sphincter deficiency since the 80'.

Objective. To evaluate long-term functional outcomes of AUSs and to determine how many men required explantation because of SUI caused by sphincter deficiency after prostate surgery.
\end{abstract}

Design, setting and participants: Men who had undergone placement of an AMS $800 \AA$ between 1984 and 1992 to relieve SUI caused by sphincter deficiency after prostate surgery were included.

Intervention. A peribulbar AUS was surgically inserted.

Outcome measurements and statistical analysis. Continence, defined as no need for pads, was assessed at the end of the follow up. Kaplan-Meier survival curves estimated the survival rate of the device without needing explantation or revision.

Results: Fifty-seven consecutive patients were included (median age 69 years; IQR: 64-72). Median duration of follow-up was 15 years (IQR: 8.25-19.75). At the end of follow-up, 25 patients (43.8\%) still had their primary AUS. Explantation of an AUS was done in nine men because of erosion $(n=7)$ and infection $(n=2)$. Survival rates, without AUS explantation, were $87,87,80$, and $80 \%$ at $5,10,15$, and 20 years, respectively. Survival rates, without AUS revision, were $59,28,15$, and $5 \%$ at $5,10,15$, and 20 years, respectively. At the end of the follow-up, in intention-to-treat analysis, $77.2 \%$ of patients were continent. 
Conclusion: In the long term $(>10$ years) the AMS $800 \circledR$ can offer a high rate of continence to men suffering from SUI caused by sphincter deficiency, with a tolerable rate of explantation and revision.

Patient summary. On the very long run (more than 10 years) AUS is able to offer high continence rate in men suffering from SUI after prostate surgery. The revision rate of the device increases with time. 


\section{Introduction}

Artificial urinary sphincters (AUSs) have been used since 1972 for the treatment of urinary incontinence (UI) [1]. It has become the gold-standard treatment for males with UI caused by sphincter deficiency [2]. The AUS improves continence and quality of life [3]. The device has largely unchanged since its introduction by Scott et al.[1], and the number of AUSs implanted each year is increasing [4,5]. The AUS is supposed to have an average lifetime of 10 years $[6,7]$; however, few studies have reported on the longer-term ( $>10$ years $)$ performance of AUSs $[7,8]$. The major postoperative complication of AUSs in the longer term is needing the device to be explanted because of erosion or infection. In addition, mechanical failure, which occurs in $2.0-13.8 \%$ of devices [9] leads to subsequent revision of the AUS.

Our goal was to report the functional results of AUSs implanted 20 years ago and to determine the mechanical-survival rate of the AMS800® in men suffering debilitating UI caused by sphincter deficiency after prostate surgery (retropubic radical prostatectomy, transurethral resection of the prostate, open prostatectomy).

\section{Materials and methods}

\section{Population}

Between 1984 and 1992, AUSs (AMS 800, American Medical Systems, Minnetonka, MN, USA) have been used to treat stress urinary incontinence (SUI) in non-neurogenic male patients in our department. The pre-implantation work-up comprised a clinical interview, analysis of voiding diaries (time and voided volumes, pad changes, incontinence episodes), a 1-hour pad test, a clinical examination, a cystoscopy and urodynamic assessment (cystomanometry and urethral-closure pressure). 


\section{Surgery}

All patients had sterile urine at the time of surgery. Antibio-prophylaxis (amoxicillinclavulanic acid) was given before surgery and was maintained until removal of the urethral catheter at day 2 after surgery. Surgery was performed by two experienced surgeons.

All patients were placed in the lithotomy position. After placing a 14-Fr urethral catheter, a median perineal incision was made. The bulbocavernosus muscles were separated and the bulbar urethra was isolated along $20 \mathrm{~mm}$. The circumference of the urethra was measured, and then the cuff, which had been previously purged, was placed in position. The cuff tube was passed through the inguinal incision into the subcutaneous tissue. An inguinal incision was made on the side of the dominant hand of the patient. The front fascia of the rectus muscle was incised and a pre-peritoneal space was created to place the balloon, which was filled with $20 \mathrm{~mL}$ of isotonic product (the cuff had been previously pressurized and the balloon was inflated to $22 \mathrm{~mL}$ ). The fascia was then closed. The pump was placed in the ipsilateral scrotum. Connections between the balloon and the pump, and between the cuff and the pump, were then carried out ensuring that air was absent from the system. Once the device had been tested, it was deactivated.

Perioperative and late surgical complications were reported according to Martin et al.'s criteria.[10] Early postoperative complications ( $<30$ days) were recorded according to the Clavien-Dindo classification.[10] The device was activated after 6 weeks. Ease of activation was defined as immediate comprehension of the functioning of the device and the ability to manipulate it by the patient. 
The patients were assessed at implantation, at AUS activation at 6 weeks post-surgery, and at follow-up visits at $3,6,12,18$, and 24 months after the procedure, and then annually. A clinical examination, pump manipulation, an X-ray examination, and post-voiding residual were assessed. Continence was defined as no need to use pads. Subjective satisfaction was assessed by asking the patient.

\section{Survival of the device}

Explantation and revision of the device were analyzed separately. Explantation was defined as complete removal of the proven or potentially infected AUS. Mechanical failure was defined as a fluid leak caused by rupture or perforation of any part, insufficient pressure, or reservoir migration. Non-mechanical problems were defined as cuff erosion and infection that led to explantation. The rates of explantation, revision, and deactivation were recorded.

\section{Statistical analyses}

Statistical analyses were performed using R (Free Software Foundation's GNU project). The AUS survival rate without needing explantation (AUS in place and functioning) and the survival rate of the AUS without revision (AUS in place and functioning) were evaluated from the date of surgery to the last follow-up visit, using the Kaplan-Meier method. Univariate analyses used Cox's model of proportional hazards (PROS PHREG) to determine the risk factors for explantation and revision. Hazard ratios were defined with a confidence interval of $95 \%$. A $p$-value of $<0.05$ was considered statistically significant. The study was conducted after the patients' written informed consent was obtained and the study was approved by the local ethics committee. 


\section{Results}

\section{Patients' characteristics}

A total of 57 consecutive patients were included in this study. The median age of patients at the time of surgery was 69 years (IQR: 64-72). Median body-mass index was 25.3 (IQR: 23.9-27.6). The characteristics of the men enrolled are listed in Table 1. Among the 57 patients, $18(31.6 \%)$ had undergone previous surgery for UI, six patients had received radiation therapy before implantation of an AUS, and one patient received an AUS because of prostate cancer. The median 1-h pad test-weight was $70 \mathrm{~g}$ (IQR: 38-100).

\section{Surgery}

Median surgical time was $85 \min$ (IQR: 66-100). The characteristics of the implanted device are listed in Table 1.

\section{Postoperative course}

The median length of hospital stay after surgery was 6 days (IQR: 7-8.7). The AUS was activated 6 weeks later. All patients had easy activation of the device. Early postoperative complications are listed in Table 2. There were five minor complications (grade I-II) and one major complication (grade III-IV). No patient died during the postoperative course.

\section{Clinical outcomes}


At the end of the follow-up, 49 patients were still alive. Median follow-up time, including men with and without the device, was 15 years (IQR: 8.25-19.75). Figure 1 shows the outcomes of the AUSs for the 57 patients. No patient was lost to follow-up. Twenty-five patients $(43.8 \%)$ still had their native AUS in place at the end of follow-up. Of the total patients, $47(82.4 \%)$ had an activated AUS at the last follow-up.

Deactivation. At the last follow-up, four patients had a deactivated device because of dementia, erosion without an explantation, regular acute urinary retention caused by gross hematuria secondary to prostate cancer recurrence, and a massive stroke, making it impossible to use the device. One patient had deactivated the device, which allowed him to be continent.

Continence. At the last follow-up, in intention-to-treat analysis, $77.2 \%$ of patients were continent. The subjective satisfaction rate reported by patients at the last visit was $89.5 \%$.

Infections. One infection occurred at 13 years after the initial implantation of the AUS and another infection occurred 3.5 years after.

Erosion. Incidences of erosion occurred at the median time of 6.25 years (IQR: 18 months-22 years). There were two peaks of occurrence: one within the first 4 years and the second at over 12 years. Overall, there were eight erosions. Erosion occurred after initial implantation of the AUS in five patients, after a revision of the AUS because of mechanical failure in 1 patient, after two revisions of the AUS in one patient, and after a third revision for one patient. One patient did not undergo explantation of his AUS (only deactivation) because of bad general-health condition.

Explantation. Explantation of the AUS was performed in nine patients because of erosion $(n=$ 7) or infection that caused erosion $(n=2)$. The 5-, 10-, 15-, and 20-year survival rates without explantation of an AUS, with it in place and functioning, was $87 \%, 87 \%, 80 \%$, and $80 \%$, respectively (Figure 2). In univariate analyses, being aged $>69$ years, having a body-mass 
index $>25$, prior radiation therapy, and the number of revisions were not significant risk factors for explantation.

Revision. The median number of revisions was one (IQR: 0-2). The 5-, 10-, 15-, and 20-year survival rates without revision of the AUS, while it was in place and functioning, was 59\%, $28 \%, 15 \%$, and $5 \%$, respectively (Figure 3 ). In univariate analyses, being aged $>69$ years, a body-mass index $>25$, and prior radiation therapy were not significant risk factors for revision.

\section{Discussion}

To our knowledge, our study reports the longest follow-up of men implanted with an AUS. We found a continence rate of $77.2 \%$ at the last follow-up and, overall, the patients' satisfaction was $89.5 \%$. These results agree with rates reported by authors in studies that had 10 -year periods of follow up [6,7]. AUS remains the gold-standard treatment for male UI caused by sphincter deficiency [2]; it has good functional outcomes and an acceptable morbidity. Table 3 summarizes the main functional outcomes for AUS in studies that have reported a $>5$-year follow-up [3,6,7,11-18].

As also reported in the literature, we found that overall satisfaction after implantation of an AUS was high, regardless of the presence of leaks or revisions [19]. The hospital stay 20 years ago was longer for this type of surgery, reflecting medical care at that time. It is import to note that the main indication for implanting of an AUS at that period was UI after benign prostate hyperplasia whereas, nowadays, radical prostatectomy is the main indication.

In our study, survival rate without explantation of an AUS at 5, 10, 15, and 20 years was $87 \%, 87 \%, 80 \%$, and $80 \%$, respectively, which is in line with previous reports $[3,6,7,11-$ 18]. The AUS is supposed to have an average lifetime of 10 years [6,7]. The major 
postoperative complication of the AUS in the long term is the need for explantation of the device because of erosion or infection. Some papers have not reported erosion and infection separately; in our study, erosion rate was $14 \%$ and infection rate was $3.5 \%$. In another study, pooled analysis of the mean rate of erosion and infection after implantation of an AUS in male non-neurogenic patients was $8.5 \%$ (range: $3.3-27.8 \%$ ) [9].

Infection and erosion generally occur within 2 years after implantation, although much later cases have been reported [20]. It is not clear whether coating the device diminishes erosion and infection rates. The AMS $800 \AA$ device is now available in some countries with a rifampicin and minocycline coating on the cuff and pump components, but not on the pressure-regulating balloon and its tubing. Surgical experience is also probably of great importance in preventing early infection and erosion. Sandhu et al. recently suggested that the learning curve for this kind of surgery does not reach a plateau, even after $>200$ surgical procedures [21]. Walsh et al. reported an increased risk of infection and erosion in patients that had undergone irradiation. However, placement of a urethral catheter without due consideration of the AUS cuff may also account for cases of late erosion [22]. The putative increased risk of erosion with prior or subsequent radiotherapy has never been proven in welldesigned and powered cohort studies using homogeneous patient populations. In our study, radiotherapy was not identified as a significant risk factor for explantation or revision, contrary to previous reports $[13,23]$.

We reported an intention-to-treat revision rate of 40.3\%. Furthermore, the 5-, 10-, 15-, and 20-year survival rates of the AUs without needing revision, and while it was still in place and functioning, dramatically decreased with time. Mechanical failure-rates varied between $2.0 \%$ and $13.8 \%$, with failures reported from 11 months to 68.1 months postinsertion [9]. Due to the retrospective nature of this study, the mechanical-failure rate might be underestimated. 
However, global reintervention rate provides an overview of complications that occur following AUS implantation and the need invasive treatment: these should be regarded as an important end-point for comparisons with other surgical alternatives.

In a pooled analysis of 549 patients (10 studies) with non-neurogenic SUI, the mean reintervention rate was computed as $26.0 \%$ (range: $14.8-44.8 \%$ ) [9]; in addition, the timing of re-interventions was mainly influenced by the underlying cause. The patients needed a mean of 1.5 re-interventions. This result is in accordance with our study, where any recurrence of urinary leakage was attributed to urethral atrophy. Urethral atrophy is a well-known late complication after implantation of an AUS, and is typically presumed when recurrence of SUI occurs during follow-up with a functioning AUS [11,19,24,25]. Urethral-tissue hypoxia has been suggested to be the main pathophysiologic mechanism [26].

Determining the rate of urethral atrophy is a complex issue because it is potentially influenced by follow-up duration, device pressure, implantation technique, and the patient's characteristics. In the only prospective study, reported by Trigo Rocha et al., two patients developed urethral atrophy after a mean of 29.4 months [24]. A history of radiation therapy has been proposed as a risk factor for urethral atrophy. However, current knowledge on urethral atrophy in non-neurogenic patients remains limited and is based on weak retrospective data.

Consequently, despite favorable outcomes and satisfaction rates after implantation, the AUS continues to be associated with the risk of local complications (i.e., atrophy, erosion, and infection) or mechanical failure. Thus, regular revisions and/or explantations are mandatory in at least $30 \%$ of AUS devices. New and more sophisticated AUS devices have been recently developed to improve function, occlusive efficiency, and biocompatibility relative to the AUS's current design [27]. The present study also underlines the necessity of only implanting 
an AUS in cognitively and motor-"valid" patients: our population included one case of dementia and one case of brain stroke. These health issues were directly responsible for the patients' inability to handle the pump, which led to needing to deactivate the AUS and a relapse of incontinence.

New AUS devices are awaited to decrease the incidence of mechanical failure and to improve urethral protection [27]. Alternatively, slings or adjustable continence therapies (proACT ${ }^{\circledR}$ ) may be of great interest as there is no device, as yet, able to manipulate voidance. However, these may create some degree of obstruction and more long-term follow-up studies are needed [2].

\section{Conclusion}

The AUS provided satisfactory long-term functional results for more than 10 years among men with SUI caused by sphincter deficiency. Not surprisingly, the device needed revision between 5 and 10 years. However, it is worth noting that $>70 \%$ of the men remained continent in the long run.

\section{References}

[1] Scott FB, Bradley WE, Timm GW. Treatment of urinary incontinence by an implantable prosthetic urinary sphincter. J Urol 1974;112:75-80.

[2] Lucas MG, Bosch RJL, Burkhard FC, Cruz F, Madden TB, Nambiar AK, et al. EAU Guidelines on Surgical Treatment of Urinary Incontinence. Eur Urol. 2012;62:1118-29. 
[3] Haab F, Trockman BA, Zimmern PE, Leach GE. Quality of life and continence assessment of the artificial urinary sphincter in men with minimum 3.5 years of followup. J Urol 1997;158:435-9.

[4] Phé V, Rouprêt M, Mozer P, Chartier-Kastler E. Trends in the landscape of artificial urinary sphincter implantation in men and women in France over the past decade. Eur Urol 2013;63:407-8.

[5] Lee R, Te AE, Kaplan SA, Sandhu JS. Temporal trends in adoption of and indications for the artificial urinary sphincter. J Urol 2009;181:2622-7.

[6] Venn SN, Greenwell TJ, Mundy AR. The long-term outcome of artificial urinary sphincters. J Urol 2000;164:702-706; discussion 706-707.

[7] Fulford SC, Sutton C, Bales G, Hickling M, Stephenson TP. The fate of the "modern" artificial urinary sphincter with a follow-up of more than 10 years. $\mathrm{Br} \mathrm{J}$ Urol 1997;79:713-6.

[8] Venn SN, Greenwell TJ, Mundy AR. The long-term outcome of artificial urinary sphincters. J Urol 2000;164:702-7.

[9] Van der Aa F, Drake MJ, Kasyan GR, Petrolekas A, Cornu J-N. The Artificial Urinary Sphincter After a Quarter of a Century: A Critical Systematic Review of Its Use in Male Non-neurogenic Incontinence. Eur Urol 2013;63:681-9.

[10] Mitropoulos D, Artibani W, Graefen M, Remzi M, Rouprêt M, Truss M. Reporting and Grading of Complications After Urologic Surgical Procedures: An ad hoc EAU Guidelines Panel Assessment and Recommendations. Eur Urol 2012;61:341-9.

[11] Elliott DS, Barrett DM. Mayo Clinic long-term analysis of the functional durability of the AMS 800 artificial urinary sphincter: a review of 323 cases. J Urol 1998;159:12068. 
[12] Gousse AE, Madjar S, Lambert M-M, Fishman IJ. Artificial urinary sphincter for postradical prostatectomy urinary incontinence:long-term subjective results. J Urol 2001;166:1755-8.

[13] Raj GV, Peterson AC, Toh KL, Webster GD. Outcomes following revisions and secondary implantation of the artificial urinary sphincter. J Urol 2005;173:1242-5.

[14] Montague DK, Angermeier KW, Paolone DR. Long-term continence and patient satisfaction after artificial sphincter implantation for urinary incontinence after prostatectomy. J Urol 2001;166:547-9.

[15] Kim SP, Sarmast Z, Daignault S, Faerber GJ, McGuire EJ, Latini JM. Long-Term Durability and Functional Outcomes Among Patients With Artificial Urinary Sphincters: A 10-Year Retrospective Review From the University of Michigan. J Urol 2008;179:1912-6.

[16] Petero Jr. VG, Diokno AC. Comparison of the Long-Term Outcomes Between Incontinent Men and Women Treated With Artificial Urinary Sphincter. J Urol 2006;175:605-9.

[17] Gülpınar O, Süer E, Gökce Mİ, Haliloğlu AH, Oztürk E, Arıkan N. Functional Outcomes and Long-term Durability of Artificial Urinary Sphincter Application: Review of 56 Patients With Long-term Follow-up. Korean J Urol 2013;54:373-6.

[18] Bordenave M, Rouprêt M, Taksin L, Parra J, Cour F, Richard F, et al. Long-term results of the treatment of urinary incontinence with bulbar implantation of artificial urinary sphincter in men: a single-center experience.Prog Urol 2011;21:277-82.

[19] Dalkin BL, Wessells H, Cui H. A National Survey Of Urinary And Health Related Quality Of Life Outcomes In Men With An Artificial Urinary Sphincter For PostRadical Prostatectomy Incontinence. J Urol 2003;169:237-9. 
[20] Duncan HJ, McInerney PD, Mundy AR. Late erosion. A new complication of artificial urinary sphincters. Br J Urol 1993;72:597-8.

[21] Sandhu J, Maschino AC, Vickers AJ. The surgical learning curve for artificial urinary sphincter procedures compared to typical surgeon experience. Eur Urol 2011;60:128590.

[22] Walsh I k., Williams S g., Mahendra V, Nambirajan T, Stone A r. Artificial urinary sphincter implantation in the irradiated patient: safety, efficacy and satisfaction. BJU Int 2002;89:364-8.

[23] Manunta A, Guillé F, Patard JJ, Lobel B. Artificial sphincter insertion after radiotherapy: is it worthwhile? BJU Int 2000;85:490-2.

[24] Trigo Rocha F, Gomes CM, Mitre AI, Arap S, Srougi M. A Prospective Study Evaluating the Efficacy of the Artificial Sphincter AMS 800 for the Treatment of Postradical Prostatectomy Urinary Incontinence and the Correlation Between Preoperative Urodynamic and Surgical Outcomes. Urology 2008;71:85-9.

[25] Petrou SP, Elliott DS, Barrett DM. Artificial urethral sphincter for incontinence. Urology 2000;56:353-9.

[26] Martins FE, Boyd SD. Artificial Urinary Sphincter in Patients Following Major Pelvic Surgery and/or Radiotherapy: Are They Less Favorable Candidates? J Urol 1995;153:1188-93.

[27] Phé V, Rouprêt M, Chartier-Kastler E. Newer and novel artificial urinary sphincters (AUS): the development of alternatives to the current AUS device. BJU Int 2013;112:E426-E428. 


\section{Figure captions}

Figure 1. Flowchart showing the outcomes of 57 implanted artificial urinary sphincters.

Figure 2. Explantation-free survival curve for men implanted with an artificial urinary sphincter.

Figure 3. Revision-free survival curve for men implanted with an artificial urinary sphincter.

\section{$\underline{\text { Tables }}$}

Table 1. Characteristics of the patients and of the implanted artificial urinary sphincters.

Table 2. Early postoperative complications according to the Clavien-Dindo classification.

Table 3. Main outcomes of artificial urinary sphincters over a 5-year follow-up period taken from the literature. 


\section{Take Home Message}

The AUS provided satisfactory long-term functional results for more than 10 years among men with SUI caused by sphincter deficiency with $>70 \%$ of the men remaining continent. Not surprisingly, the device needed revision between 5 and 10 years. 


\section{Click here to download high resolution image}

Fig1. Flowchart showing the outcomes of 57 implanted artificial urinary sphincters.

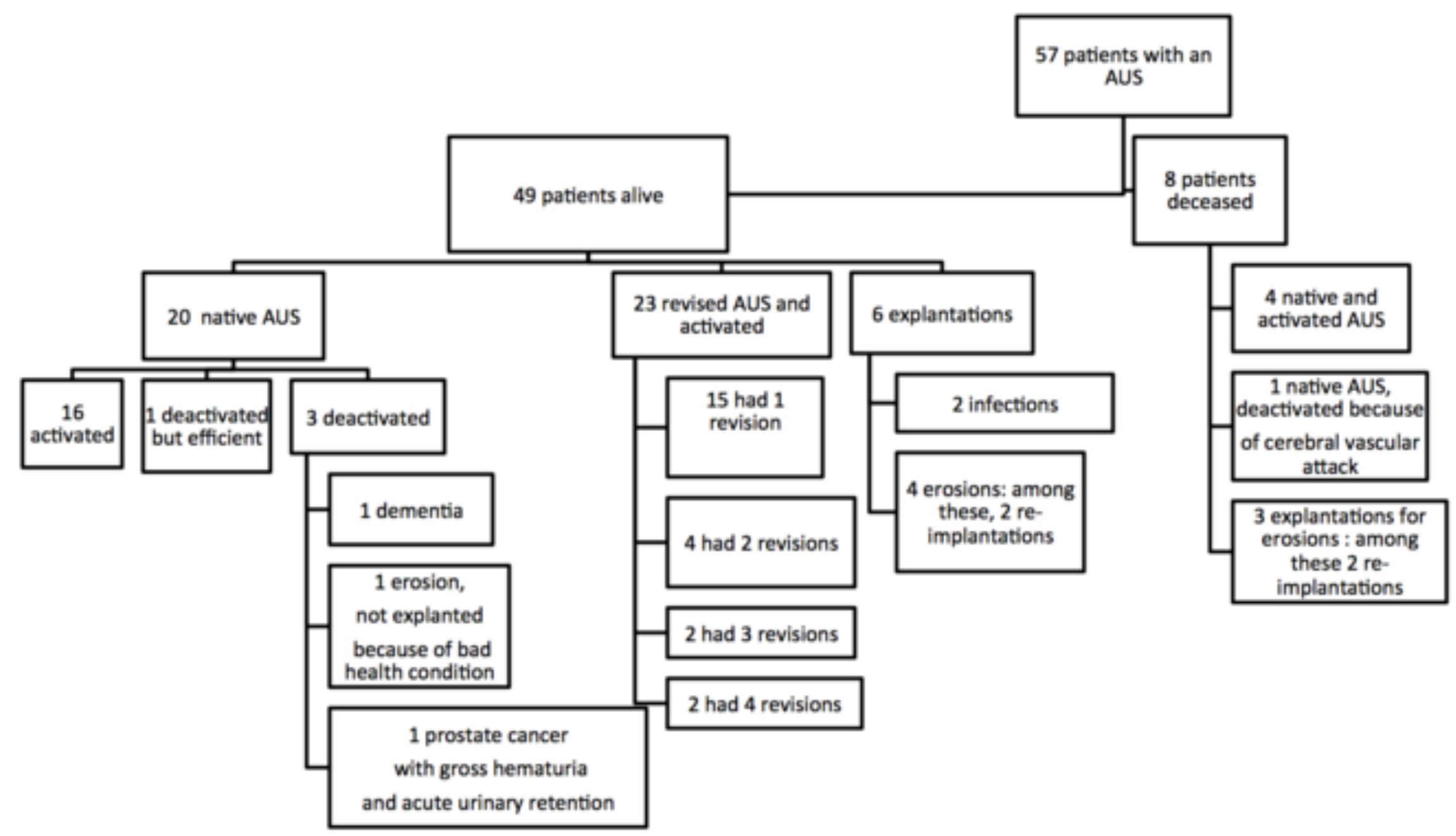


Explantation-free survival curve for the men implanted with an AUS (confident intervals are mentioned in dashed curves).

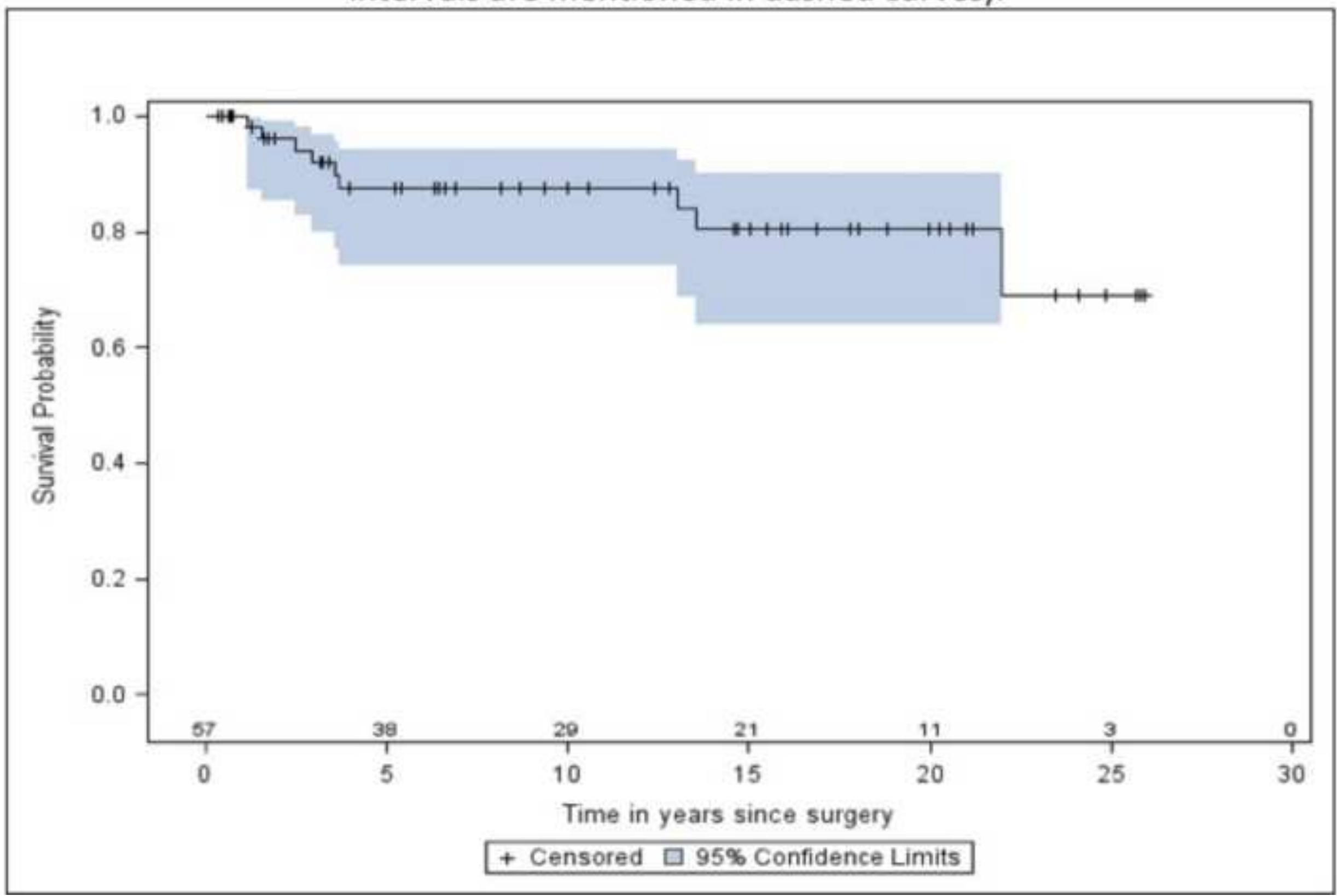


Revision-free survival curves for the men implanted with an AUS (confident intervals are mentioned in dashed curves).

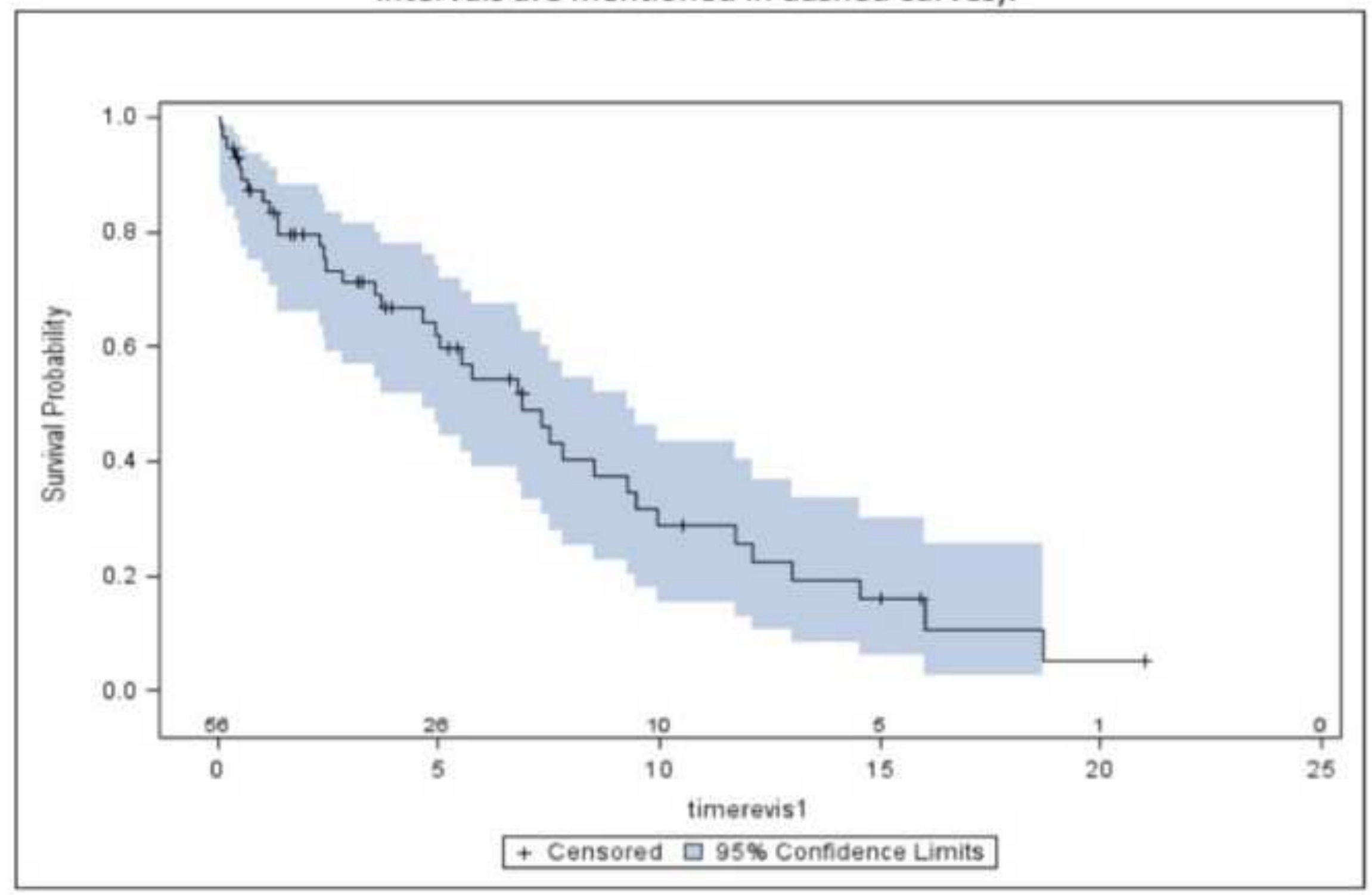


Table 1. Characteristics of patients and of the implanted artificial urinary sphincters

\begin{tabular}{|c|c|}
\hline $\mathrm{N}=57$ patients & $\mathrm{N}(\%)$ \\
\hline \multicolumn{2}{|c|}{ Type of prostate surgery leading to urinary incontinence } \\
\hline Retropubic radical prostatectomy & $6(10.5 \%)$ \\
\hline Open prostatectomy & $16(28.1 \%)$ \\
\hline Transurethral resection of the prostate (TURP) & $35(61.4 \%)$ \\
\hline \multicolumn{2}{|l|}{ No of previous surgery for urinary incontinence } \\
\hline 0 & $39(68.4 \%)$ \\
\hline 1 & $11(19.3 \%)$ \\
\hline 2 & $4(7 \%)$ \\
\hline 3 & $2(3.5 \%)$ \\
\hline$\geq 4$ & $1(1.8 \%)$ \\
\hline \multicolumn{2}{|l|}{ AUS cuff size } \\
\hline $4 \mathrm{~cm}$ & $1(1.8 \%)$ \\
\hline $4,5 \mathrm{~cm}$ & $44(77.2 \%)$ \\
\hline $5 \mathrm{~cm}$ & $5(8.8 \%)$ \\
\hline $5,5 \mathrm{~cm}$ & $5(8.8 \%)$ \\
\hline $6,5 \mathrm{~cm}$ & $2(3.6 \%)$ \\
\hline \multicolumn{2}{|l|}{ Balloon size } \\
\hline $51-60 \mathrm{cmH} 2 \mathrm{O}$ & $31(54.3 \%)$ \\
\hline $61-70 \mathrm{cmH} 2 \mathrm{O}$ & $26(45.7 \%)$ \\
\hline \multicolumn{2}{|l|}{ Pump location } \\
\hline Right & $44(77.2 \%)$ \\
\hline Left & $13(22.8 \%)$ \\
\hline
\end{tabular}


Table 2. Early postoperative complications according to Clavien-Dindo Classification

\begin{tabular}{|l|l|l|l|}
\hline $\begin{array}{l}\text { Clavien-Dindo grading } \\
\text { system }\end{array}$ & $\mathrm{n}=$ & type & Management \\
\hline I & 1 & Scrotal edema & analgesic \\
\hline II & 4 & $\begin{array}{l}1 \text { urinary tract infection } \\
2 \text { orchi-epididymitis } \\
1 \text { acute urinary retention }\end{array}$ & $\begin{array}{l}\text { antibiotic } \\
\text { antibiotic } \\
\text { bladder catheterization }\end{array}$ \\
\hline IIIa & 0 & - & - \\
\hline IIIb & 1 & $\begin{array}{l}\text { Immediate post operative } \\
\text { hematoma }\end{array}$ & $\begin{array}{l}\text { Evacuation in the operating } \\
\text { room }\end{array}$ \\
\hline IV & 0 & - & - \\
\hline V & 0 & - & - \\
\hline Total & 6 & & \\
\hline
\end{tabular}


Table 3. Main outcomes of artificial urinary sphincters over a 5-year follow-up period taken from the literature.

\begin{tabular}{|c|c|c|c|c|c|c|c|c|c|}
\hline References & $\mathrm{N}=$ & Mean age & Mean follow up (yrs) & $\begin{array}{c}\% \\
\text { continence }\end{array}$ & $\begin{array}{c}\% \\
\text { infection }\end{array}$ & $\%$ erosion & $\begin{array}{l}\% \text { urethral } \\
\text { atrophy }\end{array}$ & $\begin{array}{l}\% \text { surgical } \\
\text { intervention }\end{array}$ & AUS durability \\
\hline Elliot et al. [11] & $\begin{array}{c}184 / 323 \\
\text { narrow } \\
\text { backing } \\
\text { cuff } \\
139 / 323 \\
\text { pre } \\
\text { narrow } \\
\text { backing } \\
\text { cuff }\end{array}$ & 60.4 & 5.7 & $\mathrm{nr}$ & $\begin{array}{c}0.5 \\
3\end{array}$ & $\begin{array}{l}6.5 \\
6.0\end{array}$ & $\mathrm{nr}$ & $\begin{array}{l}17.0 \\
42.0\end{array}$ & $\begin{array}{l}75 \% \text { at } 5 \mathrm{yrs} \\
67 \% \text { at } 5 \mathrm{yrs}\end{array}$ \\
\hline Venn et al.[8] & $\begin{array}{l}100 \text { with } \\
70 \text { men }\end{array}$ & 35 & 11 & 84 & 37 & 23 & $\mathrm{nr}$ & 60 & $\begin{array}{c}\text { Male bulbar urethral cuff : } \\
\text { original device } \\
52 \% \text { at } 10 \text { yrs } \\
71 \% \text { at } 5 \text { yrs }\end{array}$ \\
\hline Gousse et al.[12] & $71 / 131$ & 72 & 7.7 & 59 & 1.4 & 4.2 & $\mathrm{nr}$ & 29.6 & $\begin{array}{l}79,4 \% \text { at } 5 \text { yrs (native AUS) } \\
88 \% \text { at } 5 \text { yrs (revised AUS) }\end{array}$ \\
\hline Raj et al.[13] & 554 & 68 & $>4.2$ & 88.5 & 0.5 & 5.2 & 14.0 & 19.1 & $79 \%$ at $5 \mathrm{yrs}$ \\
\hline $\begin{array}{l}\text { Montague et } \\
\text { al.[14] }\end{array}$ & 209 & 68 & 5.1 & 64 & $\mathrm{nr}$ & 6 & 6.6 & 12 & $88 \%$ at $5 \mathrm{yrs}$ \\
\hline Haab et al.[3] & 68 & 68 & 7.2 & 80 & $\mathrm{nr}$ & 2.9 & 8.8 & 25 & $\begin{array}{c}70 \% \text { at } 7 \text { yrs }(25 \% \text { revised and } \\
5.8 \% \text { explanted })\end{array}$ \\
\hline Fulford el al.[7] & $\begin{array}{c}61 / 68 \\
\text { with } 43 \\
\text { men }\end{array}$ & 26 & 10 & 61 & $\mathrm{nr}$ & 31 & $\mathrm{nr}$ & 80.3 & $75 \%$ at $10 \mathrm{yrs}$ \\
\hline Kim et al.[15] & 124 & 65.9 & 6.8 & 82 & 5.64 & 8.06 & $\mathrm{nr}$ & 37 & $64 \%$ at $10 \mathrm{yrs}$ \\
\hline Petero et al.[16] & $\begin{array}{c}108, \\
\text { among } \\
\text { them } 53 \\
\text { men }\end{array}$ & 63.1 & 8.1 & 62 & $\begin{array}{l}1.14 \text { men } \\
1.25 \\
\text { women }\end{array}$ & $\begin{array}{l}15.9 \text { men } \\
6.25 \\
\text { women }\end{array}$ & $\mathrm{nr}$ & 53 & 34 at 8 yrs \\
\hline $\begin{array}{l}\text { Gulpinar et } \\
\text { al.[17] }\end{array}$ & 56 & 61.8 & 8 & 46 & 7.1 & 8.9 & $\mathrm{nr}$ & 41.1 & $\begin{array}{c}50 \text { at } 3 \mathrm{yrs} \\
45 \% \text { at } 10 \mathrm{yrs}\end{array}$ \\
\hline $\begin{array}{l}\text { Bordenave et } \\
\text { al.[18] }\end{array}$ & 159 & 68.4 & 5.75 & 74.2 & 4.4 & 4.5 & 7.5 & 32.4 & 86.2 at $6 \mathrm{yrs}$ \\
\hline Present series & 57 & 69 & 15 & 77.19 & 3.51 & 17.5 & 0 & 64.2 & $\begin{array}{l}87 \% \text { at } 5 \text { and } 10 \text { yrs } \\
80 \% \text { at } 15 \text { and } 20 \text { yrs }\end{array}$ \\
\hline
\end{tabular}

NR: not reported 